\title{
IKONE BOGORODICE HODIGITRIJE DEXIOKRATOUSE I ARISTEROKRATOUSE NA BADIJI I OREBIĆIMA
}

\author{
Zoraida Demori Staničić
}

\author{
Z. Demori Staničić \\ Hrvatski restauratorski zavod \\ Služba za odjele izvan Zagreba \\ Porinova $2 \mathrm{a}$ \\ 21000 Split \\ zdstanicic@h-r-z.hr
}

\begin{abstract}
On both sides of Pelješac Channel in the middle of the East coast of the Adriatic, two icons are venerated. Both depict Virgin and Child and both belong to Franciscan order. One was on the islet of Badija, just in front of the Venetian town of Korčula, the other is on the opposite side of the Channel in church of Our Lady of Angels above Orebici on territory of Republic of Dubrovnik. Both icons are analyzed within the context of their veneration and style of Cretan icon painting of $15^{\text {th }}$ and $16^{\text {th }}$ centuries.
\end{abstract}

Key words: Cretan icons, Virgin and Child, Franciscan monasteries, Badija, Orebići

Štovanje ikona u Dalmaciji započelo je vrlo rano; najstarije sačuvane potječu iz 12. i 13. stoljeća. ${ }^{1}$ Iako se identificiraju s crkvama na Istoku one su predmet štovanja i u zapadnoj, katoličkoj crkvi gdje se najčešće vrednuju kao devocijska i likovna forma. ${ }^{2} \mathrm{U}$ dalmatinskim je crkvama nakon brojnih povijesnih i liturgijskih mijena u javnom štovanju zatečeno gotovo stotinjak ikona. One gotovo isključivo prikazuju Bogorodicu s Djetetom te su ustoličene na oltarima ili vise na zidovima lađa, kapela, sakristija te u dvoranama bratovština.

Ikone su na Zapadu svete devocijske slike koje vjernika potiču na empatički doživljaj, ali je daleki odjek njihove semantičke suštine ostao i danas prisutan ovdje u znatnoj mjeri: mnoge od njih čudotvorne su „same po sebi“, ili su povezane uz neko čudo (ozdravljenja, suze, prelijetanja, doplovljavanja). Stoljećima se čuvaju i dopunjavaju legende koje sežu duboko u njihovu neidentificiranu prošlost, dok se realni povijesni podaci gube. Starije ikone dojmljive su zbog arhaičnosti i „autentičnosti“, pa postaju "nerukotvorene", ili "naslikane rukom sv. Luke“. Nemaju jasnog porijekla, već dolaze ploveći ili leteći, što samo po sebi potencira Božje djelo, taumaturšku moć i čudotvornost. Postaju stoga predmet općeg štovanja koje se svakim neobičnim događajem multiplicira. Misticizam, neobičnost i stilski arhaizam bizantskih ikona koji traje stoljećima kao i njihova pretpostavljana i naglašavana „izvornost" koja se pratila još iz prvih dana kršćanstva, imali su za rezultat preferenciju njihove nabave.

Iz doba komunalnog ustrojstva dalmatinskih gradova u 13. stoljeću, potječu najstarije dalmatinske ikone koje, gotovo sve, uz kulturni sloj slikanih raspela, ${ }^{3}$ prikazuju Bogorodicu s Djetetom. One su u srednjevjekovnom Zadru, Splitu, Trogiru i Dubrovniku imale „političku” ulogu, naglašavajući

\footnotetext{
${ }^{1}$ G. GAMULIN, Bogorodica s Djetetom u staroj umjetnosti Hrvatske, Zagreb, 1991; Romaničko slikarstvo u Hrvatskoj, katalog izložbe Muzej za umjetnost i obrt, Zagreb, 1987, I. FISKOVIC (ed.) Zagreb 1987; Prvih pet stoljeća hrvatske umjetnosti, The First Five Centuries of Croatian Art, katalog izložbe Galerija Klovićevi dvori, Zagreb, 2006, N. JAKŠIĆ, (ed.), Zagreb, 2006. (sa starijom liliteraturom)

${ }^{2}$ Mother of God Representations of the Virgin in Byzantine Art, Catalogue of the Exhibition Benaki Museum Athens, 20002001, M. VASSILAKI (ed.), Skira Milano, 2000.

${ }^{3}$ G. GAMULIN, Slikana raspela u Hrvatskoj, Zagreb, 1983.; I. FISKOVIĆ, op. cit. (n.1).
} 
javni legitimitet paladija grada-komune. No, na žalost, nisu ni približno sačuvane u izvornom topografskom niti u stilskom kontekstu: samo je nekoliko od njih zatečeno na oltarima koji su kroz stoljeća mijenjani i modificirani, neke su prikazane na arhivskim fotografijama iz prošlog i pretprošlog stoljeća, dok je najveći njihov broj danas muzeiziran zbog umjetničke i povijesne valorizacije.

U doba kada je Mletačka Republika dalmatinske gradove-komune pripojila velikoj i dobro organiziranoj državi, ikone Bogorodice s Djetetom su od lokalnih partikularno štovanih kultova postale dio šireg, dobro zamišljenog koncepta propagiranja vladavine Serenissime od Jadrana do Egejskog mora. Upravo Mlečani, ostvarujući svoju kolonijalnu politiku panvenecijanizma uzimaju Bogorodicu za vladaricu i prije nego li sv. Markom i lavom osvajaju srca ljudi: lav sv. Marka može se doživljavati kao simbol nametnute vlasti, ali Gospa ulazi u svačija srca. Štovanje nekih Gospinih ikona u Hvaru obilježeno je jasnim političkim konotacijama usko vezanim uz ustrojstvo ovog, za Mletke važnog prometnog središta. Mletačka je vlast svetišta nastala na njihovom štovanju neupitno obilježila i označila svojim državnim grbom.

Vrlo je važno u širokoj disperziji Bogorodičinih kultova koji se šire ikonama i u čijoj je nabavci i trgovanju Venecija imala primat, ${ }^{5}$ naglasiti ulogu prosjačkih redova, franjevaca i dominikanaca. ${ }^{6}$ Djelujući propovijedanjem i preko novoosnovanih bratovština koje su međusobno bile vrlo kompetitivne, oni uređuju svetišta u kojima glavni nositelji štovanja postaju upravo ikone: franjevci na Rabu i Krapnju, splitskom Poljudu, u Hvaru, Orebićima i na Badiji, dominikanci u Korčuli, Šibeniku i Dubrovniku. Vezanost naročito franjevačkog reda za ikone Bogorodice nije neobična. Oni ih štuju i potiču im čašćenje upravo iz razloga čuvanja drevnih kolektivnih iskaza pučke pobožnosti koja ima važno značenje običaja i tradicije. Ikone čuvaju drevne predodžbe i preko ustaljenih, vjekovima prenošenih oblika štovanja Bogorodice nastavljaju oblikovati ponašanje vjernika.

U Pelješkom kanalu, jedan nasuprot drugog, susreću se dva franjevačka samostana i njihove crkve: na pelješkoj je strani u Podgorju nad Orebićima visoko je položen samostan i crkva Gospe od Anđela, ${ }^{7}$ dok je usred morskog kanala između otoka Korčule i Pelješca na malom otočiću Badiji drugi franjevački samostan Gospe od Milosti. ${ }^{8}$ Sučeljavaju se dvije franjevačke crkve, a u njima su dvije Gospe, dvije ikone Bogorodice s Djetetom koje su se, usprkos univerzalnosti kulta neupitne i sveobuhvatne zaštitnice, političkom voljom upravljačkih elita „razdvojile“. Na ovom lokalnom prostoru u kojem se od jedne do druge točke gotovo može dobaciti kamenom, dodiruju se dvije države, dva politička svjetonazora i dvije ikone koje upravo ovdje dobivaju naglašeno semantičko značenje. Jedna od njih, Gospa od Otoka, označava kolonijalnu silu koja pod likom i zaštitom Bogorodice, ${ }^{9}$ a ne alegorizirane „Venecije“, upravlja istočnom stranom Jadrana. Druga, pak, označava čuvaricu malog grada-države uz neupitno štovanje lokalnog parca, sv. Vlaha, i koja se na sve načine bori da sačuva svoju samostalnost.

Obje crkve i samostani nastali na štovanju Gospinog kulta, pripadaju istom crkvenom redu, ali različitim redovničkim državama. Badijska Gospa od Otoka pripadala je dalmatinskoj, a orebićka

\footnotetext{
${ }^{4}$ Crkve Gospe Kruvenice i Gospe od Milosti u gradu Hvaru.

${ }^{5}$ M. VASSILAKI, The hand of Angelos An Icon Painter in Venetian Crete, Lund Humphries and Benaki Museum, London Farnham Surrey 2010; Idem, The Painter Angelos and Icon Painting in Venetian Crete, Ashgate 2009; Z. DEMORI STANIČIĆ, „Kontinuitet majstora i radionica „kretsko-venecijanske škole“ od 15. do 17. stoljeća na istočnoj obali Jadrana“, Majstorske radionice u umjetničkoj baštini Hrvatske Zbornik Dana Cvita Fiskovića, FF press Zagreb, 2014. 123136 (sa starijom literaturom).

${ }^{6}$ O tome se opširnije eleborira u: Dominikanci u Hrvatskoj, katalog izložbe, Galerija Klovićevi dvori, Zagreb, 20072008, I. FISKOVIĆ (ed.), Zagreb 2011. i Milost susreta umjetnička baština Franjevačce provincije sv. Jeronima, katalog izložbe, Galerija Klovićevi dvori, Zagreb, 2010-2011, M. DOMIJAN, I. FISKOVIĆ, R. TOMIĆ (ed.), Zagreb 2010. ${ }^{7}$ Spomenica Gospe od Anđela u Orebićima 1470-1970, Omiš, 1970, J. VELNIĆ (ed.).

${ }^{8}$ D. FABIANICH, Memorie storico-letterarie sopra alcuni conventi della Dalmazia, Venezia, 1845, 33; C. FISKOVIĆ, „Samostan na „Otoku" kod Korčule“, Novo doba, god XVIII., Božićni broj, Split, 1935, 15-16; J. BELAMARIĆ, „Franjevačka crkva i samostan na Otoku kod Korčule", Prilozi povijesti umjetnosti u Dalmaciji 23, Split, 1983, 149-190.

${ }^{9}$ Taj je „Bogorodičnim panvenecijanizam" kasnije dobro objasnio i ilustrirao mletački kroničar i povjesničar Flaminio Cornaro u svojoj Notizie storiche delle apparizioni e delle immagini piu celebri di Maria Vergine santissima nella Città e Dominio di Venezia, Venezia, 1761, a Bogorodica na vrhu kupole venecijanske crkve Sta Maria della Salute koja je poput arke ukotvljena u laguni, odjevena je u odjeću Capitane del mar.
} 
dubrovačkoj franjevačkoj provinciji. ${ }^{10}$ Zanimljivo bi bilo znati kako ih je štovao puk? Svaki svoju, što je očekivano, ali da li i tada, kao što je danas, zajednički, odnosno usporedno? Naravno, svaka od njih imala je svoju svetkovinu, blagdan i feštu, procesije i zavjete, ali jesu li se Gospe kao i njihove države nadmetale za dominaciju, broj misa i priloga, zavjete i darivanja? Iz povijesnih podataka o tome malo doznajemo, no izvidno je da su obje imale snažno kultno značenje i da su im hodočastili mnogobrojni vjernici.

Franjevački Bogorodičini kultovi ilustrirani ikonama usko su lokalizirani i diferencirani nazivima, među kojima je najčešća Mater Misericordiae kao univerzalna zaštitnica. ${ }^{11}$ Ikona s otoka Badije ${ }^{12}$ časti se kao "Gospa od Otoka“, očito prema mjestu na kojem se nalazila. Njezino čašćenje traje stoljećima uz hodočašća lokalnog stanovništva na blagdan Velike Gospe i svečane ophode brodicama. Franjevački Gospin kult, po Fabijaniću, vjerojatno je vezan uz dolazak opservanata na otok oko 1392. godine, ${ }^{13}$ no značajno se širi od 1571. godine, kada je na dan svojeg Uznesenja Bogorodica po zagovoru užasnutih i preplašenih stanovnika spasila grad Korčulu od pohare i uništenja alžirskih pirata. Cijeli događaj opsade i obrane grada detaljno opisuje njegov sudionik, korčulanski svećenik Antun Rozanović. ${ }^{14}$ Nakon što je brodovlje Uluz Alija i Karakozija uplovilo u Jadran, franjevci su s Badije izbjegli u grad Korčulu i u crkvi Svih Svetih pohranili Gospu od Otoka i čudotvorno raspelo ${ }^{15}$ kao svoje najvažnije dragocjenosti. Poharavši niz dalmatinskih otoka, posebno Korčulu i Hvar, muslimanski pirati nisu uspjeli osvojiti grad zbog žestokog otpora njegovih stanovnika, pa su se povukli, a Korčulani su pobjedu pripisali Gospi.

Ikona Bogorodice s Djetetom pokrivena je srebrnim pokrovom koji ostavlja otvorena lica prikazanih. On ne ponavlja shemu slike u potpunosti, što je inače bilo uobičajeno, s obzirom da je izmijenjen položaj ruku, ali poštuje osnovnu impostaciju likova. Zanimljiv je Rozanovićev podatak kako su u vrijeme opsade Korčule u kolovozu 1571. godine, neki franjevci "odmetnici neke druge provincije" pokušali ukrasti dragocjenosti s Gospine slike. Godine 1660., kako prenosi Fabijanić, ${ }^{16}$ hercegnovski pirat Belalić ponovno je poharao crkvu i samostan na Badiji i pokrao sve dragocjenosti. Veliku Gospinu krunu s natpisom EX VOTO VINCENTII BAROCCIO, poklonio je imenovani koji je 1597. godine obnašao funkciju korčulanskog kneza. Na pokrovu se osobito naglašava odjeća Bogorodice i Isusa, pa su u srebru tehnikama iskucavanja i graviranja prikazane dugačke ukrašene haljine raskošnih nabora, uz dodatak raznobojnih gema na pripasanim pojasevima. Posebno je istaknuta Gospina podignuta lijeva ruka u kojoj drži neidentificirani predmet, a koja ne ponavlja slikani prikaz. Veo od srebrenog lima oko njezina lica kasniji je dodatak, jednako kao i brojne zavjetne pločice s likovima vjernika, dijelova tijela, krune i nakit.

Ikona Bogorodice s Djetetom uokvirena je pozlaćenim izrezbarenim renesansnim okvirom tabernakul tipa iz 16. stoljeća koji je po lokalnoj predaji izrađen u Dubrovniku, iako pripada širokoj skupini sličnih oltarića iz razdoblja renesanse. U franjevačkoj crkvi na Badiji ikona je bila postavljena

${ }^{10}$ J. BELAMARIĆ, 150-151, (n. 8); Z. PEŠORDA, „Prilog povijesti franjevaca u srednjevjekovnom Dubrovniku“, in Croatica Christiana Periodica, Vol. 24 No. 45, lipanj 2000, 29-57.

${ }^{11}$ I. PRIJATELJ PAVIČIĆ, Kroz Marijin ružičnjak, Split, 1998., 57-63; J: BATELJA P: BATELJA, Bogorodica Zaštitnica u Hrvata. Teološki i povijesno-umjetnički pristup, Zagreb, 2014.

${ }^{12}$ A. CRNICA, Hrvati i Marija Nacrt djela Gospina Hrvatska, Zagreb, 1953., 150-151, Z. DEMORI STANIČIĆ, „Bogorodica s Djetetom „Gospa od Otoka“, Milost susreta, Zagreb, 2010, 155-156.

${ }^{13}$ D. FABIANICH, 33, (n. 8).

${ }^{14}$ A. ROZANOVIĆ, Obrana Korčule, prev. P. Franasović, ur. I. Matijaca, Korčula 1971; V. FORETIĆ, „Turska opsada Korčule g. 1571“, in Vesnik Vojnog muzeja 5, Beograd, 1958, J: BELAMARIĆ, 165, (n. 8).

${ }^{15}$ Skulptirano drveno polikromirano raspelo pripisano je splitskom kanoniku Jurju Petroviću, a danas je izloženo na oltaru u crkvi Gospe od Anđela u Orebićima. I. FISKOVIĆ, „Prijedlog za kipara Jurja Petrovića“, in Peristil 8-9, Zagreb, 1966, 75-93.

${ }^{16}$ D. FABIANICH, 33, (n. 8.). 


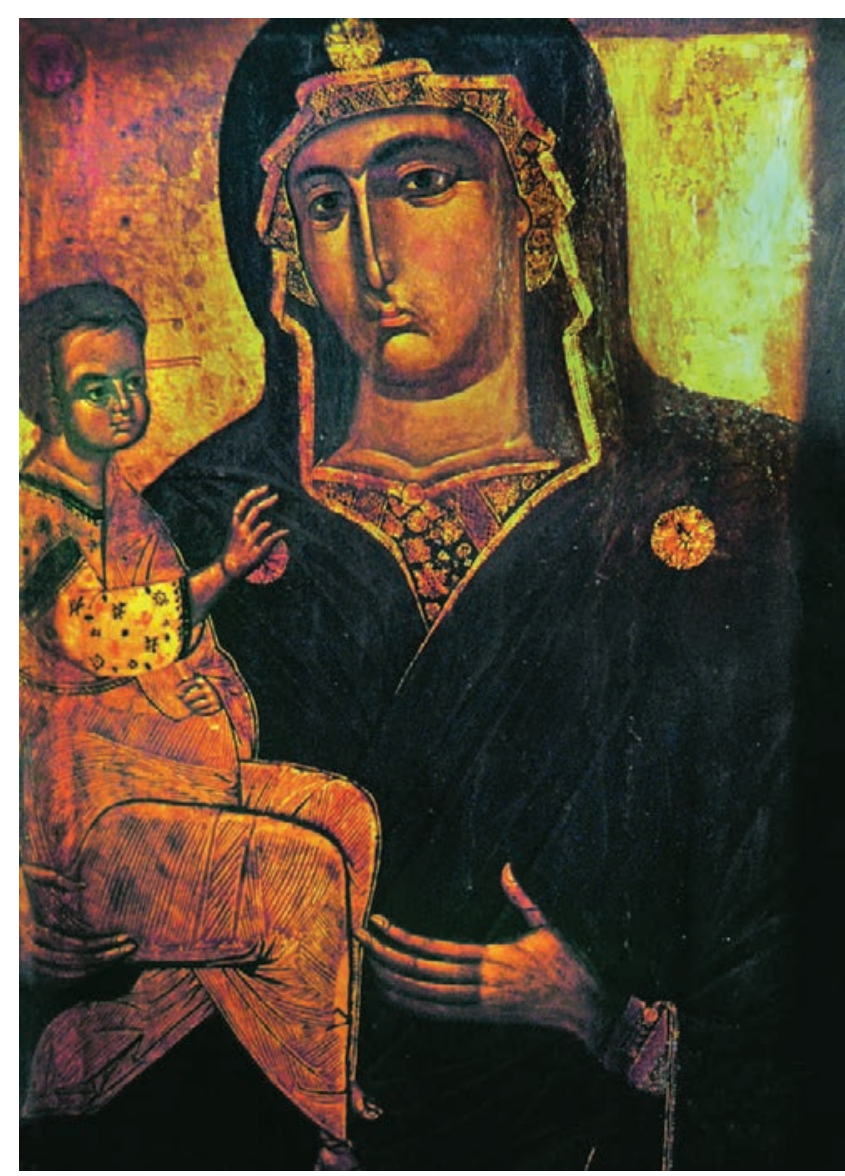

Sl. 1. Bogorodica s Djetetom „Gospa od Otoka“ prva pol. 15. st., Korčula, Opatska riznica. Izvor: D. Tulić,

N. Kudiš, Opatska riznica, katedrala i crkve grada Korčule, Korčula 2014.

Fig. 1. Virgin and Child "Our Lady of the Island", first half of the $15^{\text {th }}$ century, Korcula, Cathedral Treasury.

From: D. Tulić, N. Kudiš, Opatska riznica, katedrala i crkve grada Korčule, Korčula 2014. usred drvenog pozlaćenog oltara serlijevskog tipa ${ }^{17}$ sve do 1950. godine, kada su franjevci bili prisiljeni napustiti samostan čije su umjetnine i liturgijska oprema raspršeni unutar franjevačke provincije Sv. Jeronima. ${ }^{18}$ Dugo je vremena bila izložena štovanju vjernika u katedrali sv. Marka u Korčuli, ${ }^{19}$ dok se trenutačno nalazi u Opatskoj riznici u Korčuli ${ }^{20}$ čekajući obnovu badijskog svetišta.

Ikona prikazuje Bogorodicu s Djetetom u shemi Hodigitrije Dexiokratouse, ${ }^{21}$ koja drži Isusa na svojoj desnoj strani. Inače ikone Putovoditeljice Bogorodicu s Djetetom najčešće prikazuju kao Aristerokratousu tj. sa Isusom na lijevoj strani, kojeg majka pokazuje desnom rukom. ${ }^{22} \mathrm{Na}$ badijskoj ga ikoni, međutim, drži na desnoj strani grudiju, dok ljevicu podiže do visine struka. Glavu je Gospa lagano nagnula udesno prema Isusu. Odjevena je u raskošnu zlatom izvezenu haljinu - hiton, koji se u trokutnom vratnom izrezu otkriva u obilju zlatnih vrpci i sitnog polimorfnog ukrasa raskošne tkanine, kao i na orukavlju-epimanikionu podignute lijeve ruke. Preko haljine prebačen je klasični tamnoplavi plašt - maforion obrubljen zlatnom bordurom i markiran s tri zvijezde: na ramenima i nad čelom. One označavaju vječno svjetlo nad Bogorodičinim likom, te njezino djevičanstvo prije, za vrijeme i poslije Rođenja.

Pod maforionom se na glavi nazire bogato ukrašena grčka kapa koja u tradiciji odijevanja bizantskih vladarica vezuje kosu; ona je horror vacui potpuno izvezena zlatnim nitima, stvarajući raznovrsni usitnjeni geometrijski ukras

rombova, trokuta i zvijezda. Ispod nje nazire se Gospino desno uho iscrtano dvostrukom kružnom bijelom linijom. Lice joj je ovalno izduženo, narumenjenih obraza i oivičeno tamnim sjenama. Posebno se ističu rumene kružnice na obrazima na način obrade inkarnata romaničkog slikarstva. Čelo je nisko i vrlo plitko, a ispod njega usađene su velike smeđe oči linearno naglašenih dvostrukih vjeđa i kapaka s plitkim lukovima tamnih, debelih obrva krivuljom spojenih u korijenu nosa. Nos je naglašeno dugačak i uzak, s okruglim završecima na dnu. Precizno je konturiran. U blagoj se kosini spušta prema ustima

${ }^{17}$ D. PREMERL, „Sebastiano Serlio i tri oltara u Dalmaciji“, in Prilozi povijesti umjetnosti u Dalmaciji, 42 (2011.), 275285. Oltar je zbog restauriranja demontiran iz crkve.

${ }^{18}$ J. BELAMARIĆ, 169-171, 184, (n.8.).

${ }^{19}$ B. BANIČEVIĆ, Katedrala i Opatska riznica sv. Marka, Korčula, 1996, 24-26;

${ }^{20}$ D. TULIĆ N. KUDIŠ, Opatska riznica, katedrala i crkve grada Korčule, Korčula, 2014, 30-32.

${ }^{21}$ D. MOURIKI, ,Variants of the Hodegitria on Two Thirteenth-Century Sinai Icons", Cahier Archeologiques 39, Paris, 1991, 153-182; N. CHATZIDAKIS, „A Byzantine Icon of the Dexiokraousa Hodegitria from Crete at the Benaki Museum", Mother of God Represenation of the Virgin in Byzantine Art, ed, M. Vassilaki, Benaki Museum Athens Skira Milano, 2000, 337-414 (sa starijom literaturom).

22 V. LAZAREV, „Studies in the Iconography of the Virgin“, in Art Bulletin XX/I, 1938, 26-65. 
koja su simetrično pravilna: sitne narumenjene usnice ravno završavaju, a gornja je naglašena središnjom brazdom. Gospini obrazi blago su zaobljeni, jednako kao i istaknuta okrugla brada obrubljena s gornje strane tamnom sjenom.

Isus svečano sjedi u majčinu krilu, lagano ukošenog tročetvrtinskog tijela i visoko podignutih paralelno postavljenih nogu koje se u koljenima lome pod pravim kutom. Sudeći prema podignutoj desnoj ruci kojom blagoslivlja, odjeven je u svečanu bijelu haljinu-hiton s clavusom, izvezenu sitnim raznobojnim cvjetićima. Oko hitona omotava se zlatno narančasti plašthimation potpuno ispunjen linearnom mrežom hrisografija. On obavija dječje tijelo spuštajući se niz Isusovo lijevo rame širokim naborom alla antica, potpuno mu prekrivajući ruku, dok je spuznuo s podignute desnice otkrivajući rukav haljine. Rub himationa se u naglašenom zamahu i oštrim lomovima tkanine povija i podvlači pod Isusove noge. Isus blagoslivlja majku podignutom desnom rukom na "grčki način“, spojenog prstenjaka i palca, dok u lijevoj drži smotani, jedva vidljivi svitak kojeg okomito oslanja o trbuh. Himation ne pokriva noge u potpunosti, jer ispod njega vire bosa stopala koja su u potpunoj suprotnosti s raskoši Isusovog carskog ornata, no kao zanimljiv detalj pokazuju Isusovu ljudsku prirodu i ranjivost, prefigurirajući Muku i Oplakivanje. Sitno proporcionirana glava u odnosu na volumen tijela postavljena

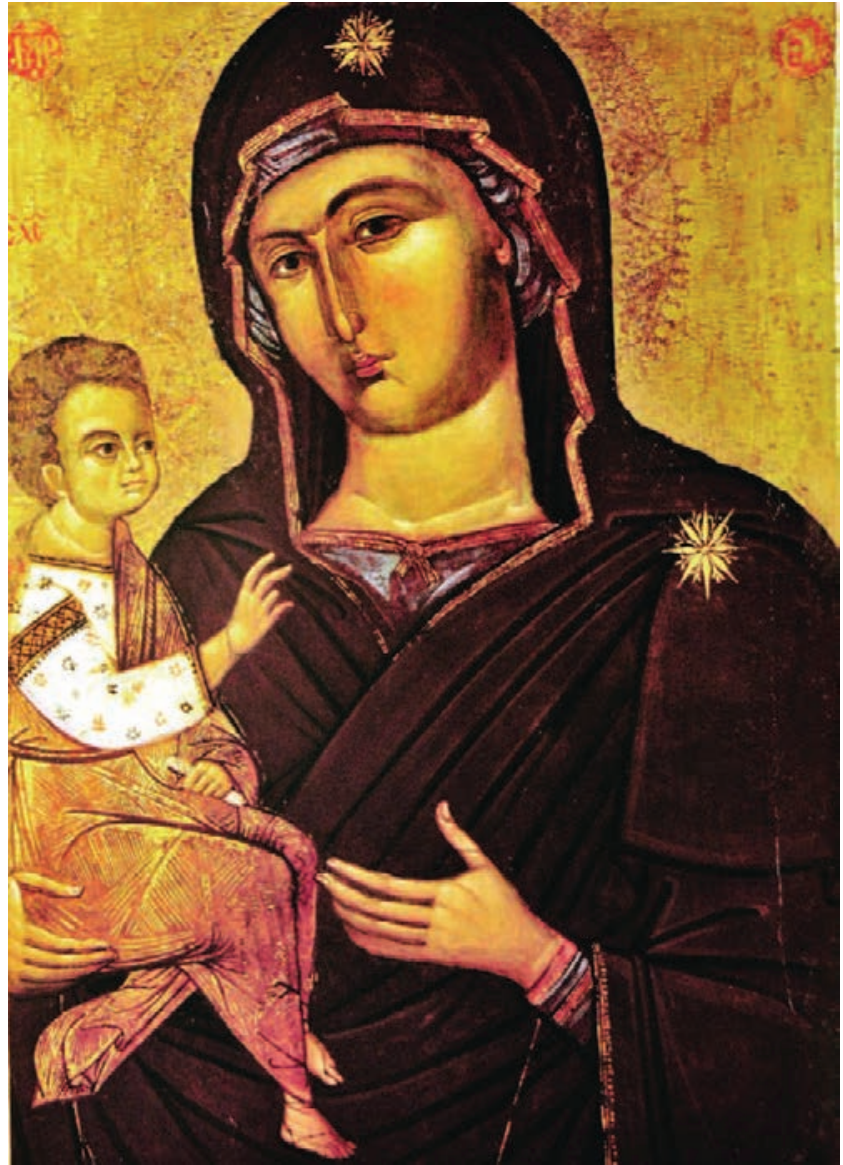

Sl. 2. Bogorodica s Djetetom, druga pol. 15. st., Venezia, Scuola di San Rocco. Izvor: D. Tulić N. Kudiš, Opatska riznica, katedrala i crkve grada Korčule, Korčula 2014.

Fig. 2. Virgin and Child, second half of $15^{\text {th }}$ century, Venezia Scuola di San Rocco. From: D. Tulić N. Kudiš, Opatska riznica, katedrala i crkve grada Korčule, Korčula 2014. je na snažnom vratu na kojem su kao i na Bogorodičinom specifičnim linijama u obliku plitkog „V“ naglašeni nabori kože. Čelo je izrazito visoko, sa zaliscima, koje uokviruje smeđa kosa počešljana u pravilne uvojke svijetlih odbljesaka od kojih se dva slobodno spuštaju na čelo. Posebno je vidljiva okrugla ušna školjka koja se sužava u donjem dijelu. Također mu se na licu ističu velike, širom otvorene smeđe oči, podignute prema Bogorodici. Nos je kratak, mesnat i precizno ocrtan, a obrazi s rumenim kružnicama i brada su okrugli. Aureole se naziru u tragovima jer ih je potpuno prekrila novija pozlata, ali se mogu prepoznati sitne punce. U gornjim kutovima slike dva su crvena medaljona s identifikacijskim natpisom Bogorodice MP $\Theta Y$.

Inkarnat je modeliran kombiniranjem crvenkastih tonova uz debele zeleno-smeđe sjene koje oivičuju lica, vrat i ruke. Uz naglašenu dekorativnost ukrasa na draperijama Gospine haljine i kape, na badijskoj je ikoni karakteristična i izvedba inkarnata tankim potezima kista. Uz, za ikone inače tipične bijele linije oko očiju, vrlo fini potezi uočljivi su i na licima i rukama, što daje dojam titranja površine. Mjestimično se uz uobičajene crne, primjećuju i atipične bijele konture. Ovakve poteze slikar postavlja slobodno i vješto. Prema tipologiji lica Bogorodičino je naglašeno arhaično što je ranije navodilo na datiranje ikone u 13. i 14. stoljeće. No svježe Isusovo dječačko, iako uozbiljeno lice, nedvojbeno proizlazi iz tipologije koju, baštineći modele venecijanskih slikara Trecenta, razvijaju kretski slikari od kraja 14. stoljeća, stvarajući prototip koji će u kontinuitetu trajati sve do 18. stoljeća. Naglašeno i slobodno ukrašavanje draperija također proizlazi iz očitog utjecaja venecijanskog gotičkog 
slikarstva. Ikonu Gospe od Otoka stoga treba pripisati ambijentu kretskog slikarstva prve polovine 15. stoljeća i pripisati kvalitetnom slikaru koji, iskoračivši iz kanona bizantskih ikona, teži kreativnosti i izražajnosti. U mletačkoj bratovštini sv. Roka (Scuola di San Rocco) sačuvana je ikona koja je blizanka badijskoj Bogorodici s kojom gotovo do u detaljê dijeli ikonografsku shemu i ukras, dok joj je slikarska egzekucija nešto slabija. Ovu ikonu datira se na kraj 15. ili na početak 16. stoljeća. ${ }^{24}$

Činjenica postojanja dvije identične ikone otvara pitanje prototipa po kojem su nastale. Problem prototipa ili pralika važna je tema bizantskog slikarstva. Prema ranim crkvenim ocima ikona izvire iz Boga; cijeli je svijet neprekidni slijed slika koje sve proističu iz prototipa, odnosno od samog Boga. U istočnoj crkvi kult prikaza Isusa Krista, Bogorodice ili pojedinih svetaca neprekinuto je Božje stvaranje, što samo po sebi jamči odnos apsolutne istine između onog što se reproducira i onog što je reproducirano. Bizantska umjetnost kao općeprihvaćeno ishodište ikona započinje obnavljajući model - prototip koji je u sebi već završen i nepromjenjiv, a vjernost njemu je intelektualna, a ne stilska operacija. Kao što prikaz na ikoni nije puka ilustracija već odražava pralik - dakle ikona stvarno jest osoba koju prikazuje $e^{25}$ - i identifikacijski natpis na isti način odražava pralik. Čašćenje se odnosi i na lik i na ime prikazanog. ${ }^{26}$ Kratice MP $\Theta Y$ i IC XC kao jezični znak nisu stvar empirije, već ontološka potvrda vizualnog znaka. Slikanjem ikone koja je već utemeljena u kultu kopira se prihvaćeni i štovani obrazac. Novi prikaz tako ne postaje puka reprodukcija, već štovana i u štovanjem prihvaćena kopija u kojoj samo stil slikarske realizacije može biti podložan promjeni. Izvornik i kopija često su građeni u sasvim različitom umjetničkom sustavu što je logično i očekivano s obzirom na protok vremena i mijene stilova, ali je znakovni sustav istovjetan. Kopije starijih čudotvornih ikona i same postaju čudotvorne, jer svaka od njih nosi snagu svojeg prototipa-pralika, odnosno osobe koju prikazuje.

U ovom kontekstu ikonama s Badije i iz Venecije može se pridružiti još jedna iz Dalmacije koja je vrlo slična: Bogorodica s Djetetom iz crkve sv. Duha u Šibeniku, danas u crkvenom muzeju u crkvi sv. Barbare. ${ }^{27}$ Prikazuje istu shemu Dexiokratouse. Desnom rukom pridržava Isusa, dok lijevu drži podignutu na prsima, pokazujući ga dlanom dugačkih koščatih prstiju od kojih su dva srednja spojena što može označavati dvojnu prirodu Kristovu. Gospa je glavu lagano priklonila udesno prema Isusu. Odjevena je u modru haljinu koja se i ovdje otkriva u trokutnom vratnom izrezu s obrubnom zlatnom vrpcom. Preko haljine prebačen je klasični purpurni maforion s resama koji joj prekriva i glavu na kojoj se vidi grčka kapa. Ukrašen je točkastom zlatnom bordurom, te s dvije velike zlatne zvijezde na ramenima koje imaju oblik okruglih, višelatičnih cvjetova. Boja haljine uvijek je u kontrastnom odnosu s bojom plašta. Kod starijih je ikona haljina najčešće crvena, a plašt je plave boje. Od 15. stoljeća odnosi se obrću. Simbolika crvene i plave vrlo je važna u označavanju Krista i Marije. Crvena boja, naime, označava božanstvo i carsku prirodu (usporedba s carskim grimizom), dok plava naglašava poniznost, humanost i osjećajnost. Bogorodičino je lice izrazito izduženog i ovalnog nepravilnog oblika, oivičeno na rubovima tamnim mrkim sjenama. Čelo je i ovdje vrlo plitko, a ispod njega su velike smeđe oči linearno naglašenih dvostrukih vjeđa is debelim plitkim lukovima tamnih

\footnotetext{
${ }^{23}$ Dimenzije Gospe od otoka su 62 x $43 \mathrm{~cm}$, a venecijanske ikone $61 \times 42 \mathrm{~cm}$.

${ }^{24}$ A. RIZZI, „Le icone bizantine e postbizantine delle chiese veneziane“, in Thesaurismata 9, Isituto Ellenico di studi bizantini e postbizantini, Idem, „Le icone bizantine e postbizantine delle chiese veneziane“, Thesaurismata 9, Isituto Ellenico di studi bizantini e postbizantini, Venezia, 1979, 286, kat. 75; D. TULIĆ N. KUDIŠ, 32 (n. 20).

${ }^{25}$ B. A. USPENSKI, Poetika kompozicije Semiotika ikone, Beograd 1979, 291-294.

${ }^{26}$ Isto, 291-292. Nije nevažno da se i na slikama zapadnog slikarstva sve do u 15. stoljeće često javljaju natpisi koji označavaju imena svetaca. Stoga nije pretjerano ustvrditi da su natpisi i kratice svojstveni općem jeziku srednjovjekovne umjetnosti. Oni nisu namijenjeni razumijevanju nego unutrašnjem sakralnom poistovjećenju i utvrđivanju ontološke veze između lika i imena. Kao dokaz ovoj tezi može ići u prilog i činjenica da mnoge ikone i slike na zapadu često imaju natpise na grčkom jeziku.

${ }^{27}$ K. KALAUZ, Iz riznice srednjevjekovnog slikarstva Šibenika, Povremene izložbe Muzeja grada Šibenika IL, Šibenik 1972, kat. 16.
} 


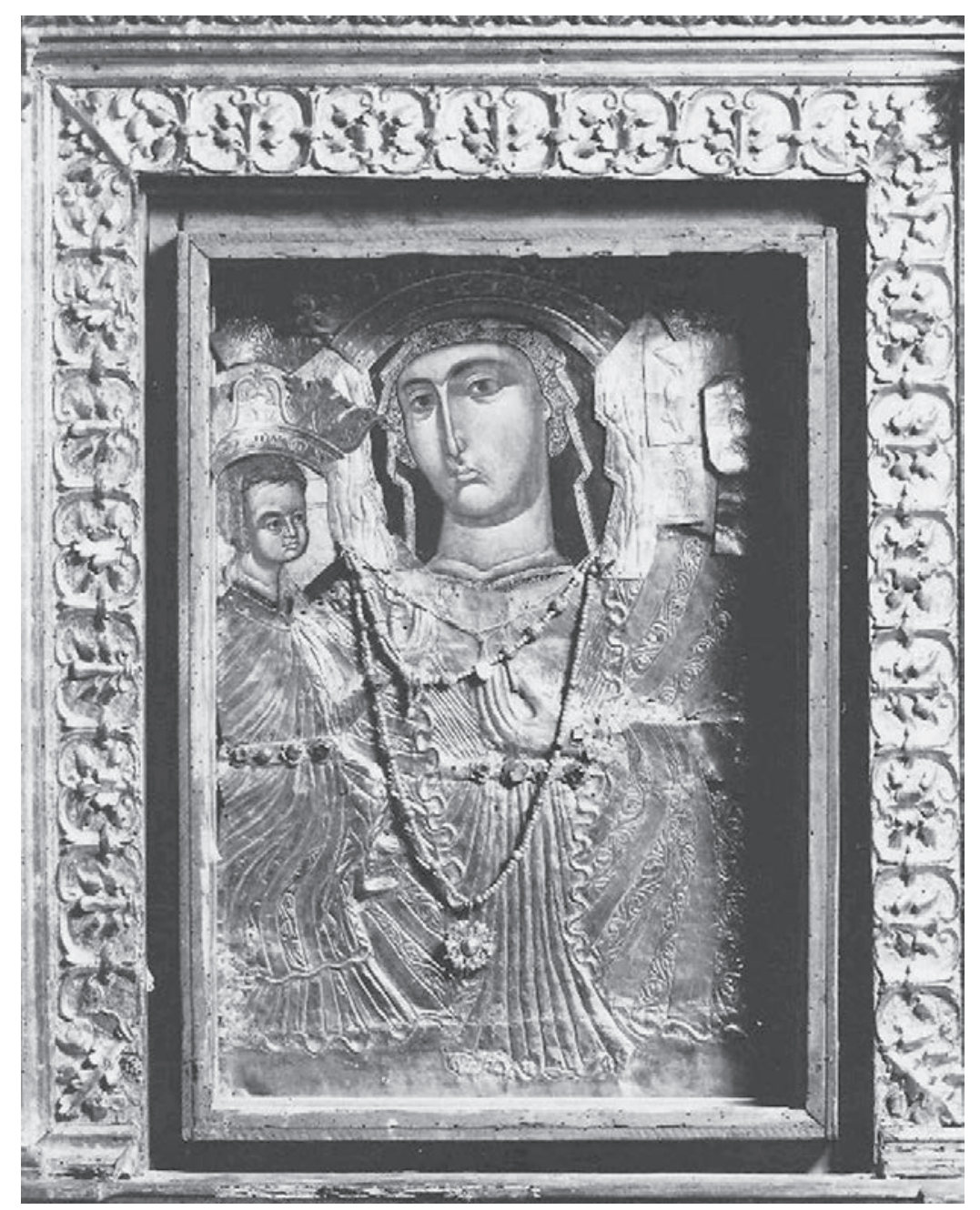

Sl. 3. Bogorodica s Djetetom „Gospa od Otoka“ sa srebrenim pokrovom. Fotografija: Živko Bačić Fig. 3. Virgin and Child "Our Lady of the Island" with silver cover

obrva spojenih u krivulji korijena nosa. Bjeloočnice su zamućene, što oku daje sjetan, odsutan izraz. Nos je dugačak i ravan, precizno konturiran. Površinski osvijetljen, spušta se prema ustima, koja su pravilna, rumenih malenih usnica spuštenih krajeva. Gornja je usnica naglašena središnjom brazdom. Gospini izduženi obrazi su mekani, kao i okrugla i vrlo izbočena brada, obrubljena s gornje strane tamnom sjenom.

Isus svečano sjedi u majčinu krilu, lagano ukošenog tijela i paralelno postavljenih izduženih nogu. Stopala nedostaju, što upućuje na skraćivanje ikone. Odjeven je u svečani bijeli hiton izvezen sitnim raznobojnim cvjetićima s clavusom i zlatno-narančasti himation, naglašenih, oštro lomljenih hrisografija. Podignutom desnom rukom blagoslivlja na "grčki način“, a u lijevoj, pokrivenoj plaštem, drži tanki smotani svitak oslanjajući ga na svoje lijevo bedro. Sitnije proporcionirana glava postavljena je na snažnom vratu koji je kao i Gospin ocrtan osvijetljenim naborima kože. Sitno lice uokviruje razbarušena smeđe-crvena kosa svijetlih odbljesaka. Oči su mu također sitne, kao i savijeni nos, što licu daje starmali izraz odrasle osobe. Oko glava ističu se raskošne aureole ispunjene sitnim ukrasom, koji je finim zlatarskim alatkama ugraviran i ukucan u zlatnu površinu; lukovi, vitice, cvjetići i kružići čine bogati ukras.

Inkarnat je modeliran uz kombinaciju crvenkastih tonova sa zeleno smeđim sjenama koje oivičuju obraze i vrat uz naglašene crne konture. Bogorodičino je lice naglašeno ekspresivno, jednako kao i njezine velike šake s izduženim koščatim prstima. No Isusovo, koji ovdje ima neuobičajenu strogost i namrgođenost, proizlazi iz bizantske tipologije dječaka Isusa kao odraslog i zrelog muškarca i razli- 


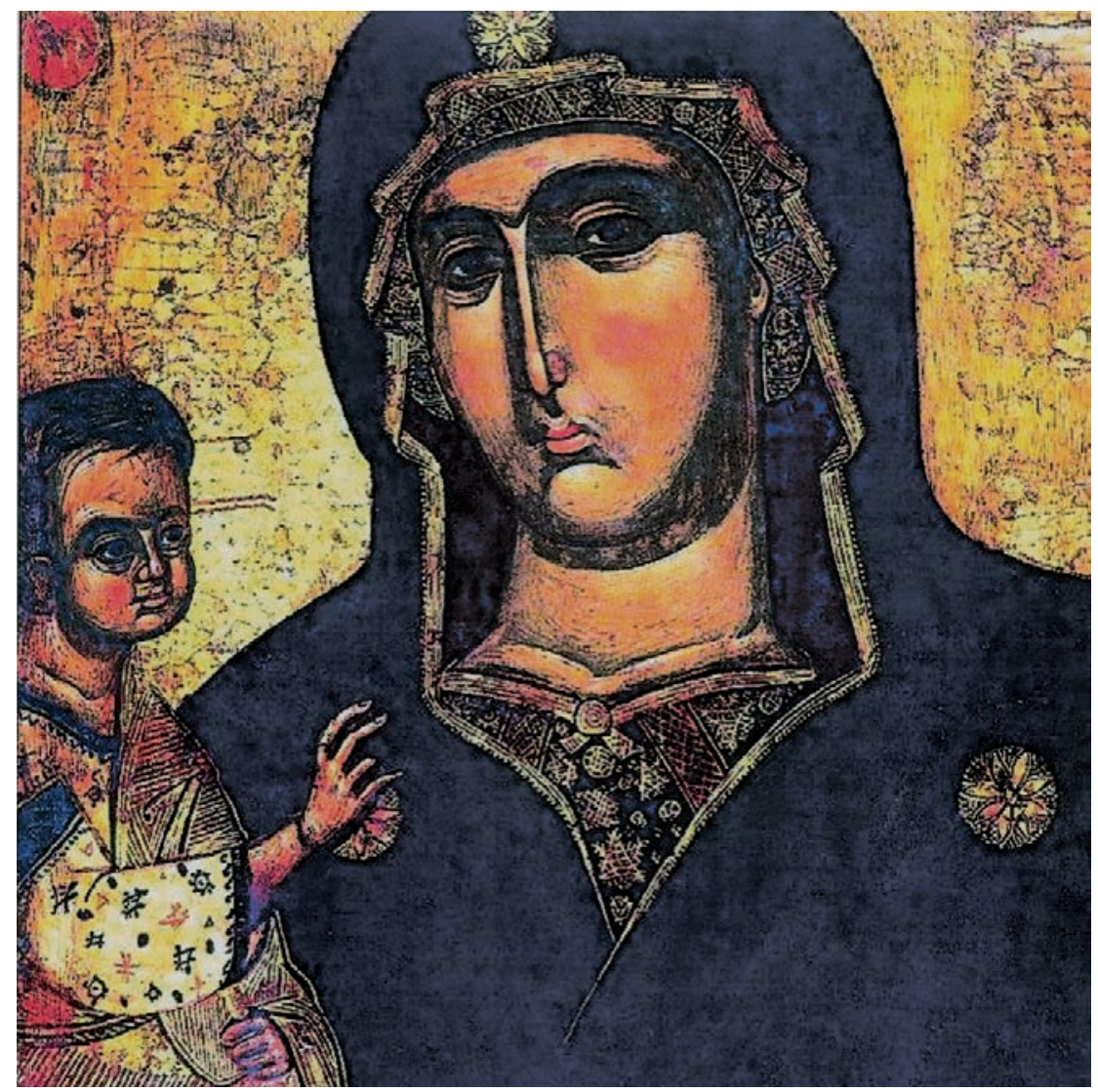

Sl. 4. Bogorodica s Djetetom „Gospa od Otoka“, detalj. Izvor: razglednica Fig. 4. Virgin and Child "Our Lady of the Island", detail from a postcard

kuje se od onog na badijskoj Gospi. I šibensku ikonu, usprkos snažnom arhaičnom dojmu bizantizma, možda također treba pripisati kretskim slikarima s početka 15. stoljeća, posebno zbog gotičkih ukrasa aureole, no ona je morala nastati nešto ranije od Gospe od Otoka. Dugački Gospini prsti s nacrtanim noktima, uz njezino izražajno lice, namjerni su arhaizam koji asocira na drevne ikone, no osvjetljavanje inkarnata bijelim odbljescima, posebno na zapešćima šaka, oko očiju i na vratu, „izdajnički“ su detalji kojima kretski slikari od 15. stoljeća postižu plastičnost. Gospa iz Šibenika čak je izražajnija od Gospe od otoka, upravo zbog arhaizama i blagih distorzija protagonista. Kao nešto kasnija generacija kretskih ikona, badijska donekle ublažava ekspresivnost, pa lica prikazanih postaju blaža i dopadljivija, šake se umanjuju, a bijeli odbljesci zamjenjeni su diskretnim toniranjem. Slikar badijske ikone doslovno se igra kistom, uživajući u iscrtavanju bogatog i raznolikog ukrasa, ali i inkarnata.

Na temelju poznatih podataka o ikonama na Istoku i Zapadu nije sasvim jasno koji bi mogao biti prototip opisanih ikona. Dexiokratouse nisu baš česte u slikarstvu i brojem ih premašuju Hodigitrije Aristerokratouse, pa i Glykofilouse s Djetetom na desnoj strani. Vrijedi primijetiti da je Dexiokratousa i poznata Bogorodica s Djetetom s kraja 13. stoljeća iz crkve sv. Andrije na Pilama u Dubrovniku, danas u riznici dubrovačke katedrale. ${ }^{28}$ Njezina se ikonografska shema podudara: isti tričetvrtinski okret Isusovog tijela, naklon Gospine glave. Usprkos oštećenjima uočljiv je uz zlatnu široku borduru Gospinog maforiona detalj grčke kape koja je žarkocrvena i prošarana hrisografijama koje tvore mrežu rombova. Isti će se motiv na sličan će način ponoviti stoljeće kasnije na badijskoj ikoni. Iako je dubrovačka ikona znatno oštećena, može se zaključiti da je njezin kolorit bio vrlo živ, s tragovima suzvučja cinobera i plave boje Isusovog himationa i hitona.

${ }^{28}$ Z. DEMORI STANIČIĆ, „Benediktinski slikarski krug južne Italije i Dalmacije(?), Bogorodica s Djetetom“, Prvih pet stoljeća hrvatske umjetnosti, Galerija Klovićevi dvori, Zagreb, 2006, 304-305. 
Skupini ranih Dexiokratusa pripada i Bogorodica s Djetetom iz crkve San Martino dei Buonomini u Firenci datirana u 13. stoljeće, poznata iz stare fotografije, ${ }^{29}$ koja doduše ne pokazuje Isusa podignutom desnom rukom, već ga njom pridržava preko nogu. No uočljiv je vrlo sličan trokutni vratni izrez kao i naglašeni nabori na vratu majke i djeteta. Cudotvorna ikona Bogorodice s Djetetom iz 13. stoljeća zvana Madonna Costantinopolitana iz crkve sv. Justine koja je zaštitnica Padove također je Dexiokratousa, kao i poznate duečentističke Madonna sotto $i$ organi iz Pise $^{30}$ i Madonna Greca iz Grottaferate. ${ }^{31}$ Nekoliko sinajskih ikona iz 13. stoljeća ${ }^{32}$ dijeli shemu s Djetetom na desnoj strani u tročetvrtinskom okretu s rotulusom u desnoj ruci, ali bez karakterističnog trokutnog izreza Gospinog maforiona niti sklonosti ukrasu, pa sve pokazuju tradicionalni stil komnenskg slikarstva. ${ }^{33}$

Najstarija među Dexiokratousama je Bogorodica iz Muzeja bizantske kulture u Solunu datirana oko 1200. godine. I ona pokazuje Bogorodicu glave lagano priklonjene Isusu kojeg pokazuje, dok ju on, sjedeći visoko na njezinoj desnoj ruci kojom ga odozdo drži, blagoslivlja podignutom desnom rukom. U lijevoj drži uočljivi crveni svitak. Na licu koje ima dostojanstveni izraz dominiraju velike bademaste oči koje su naglašeno kontu-

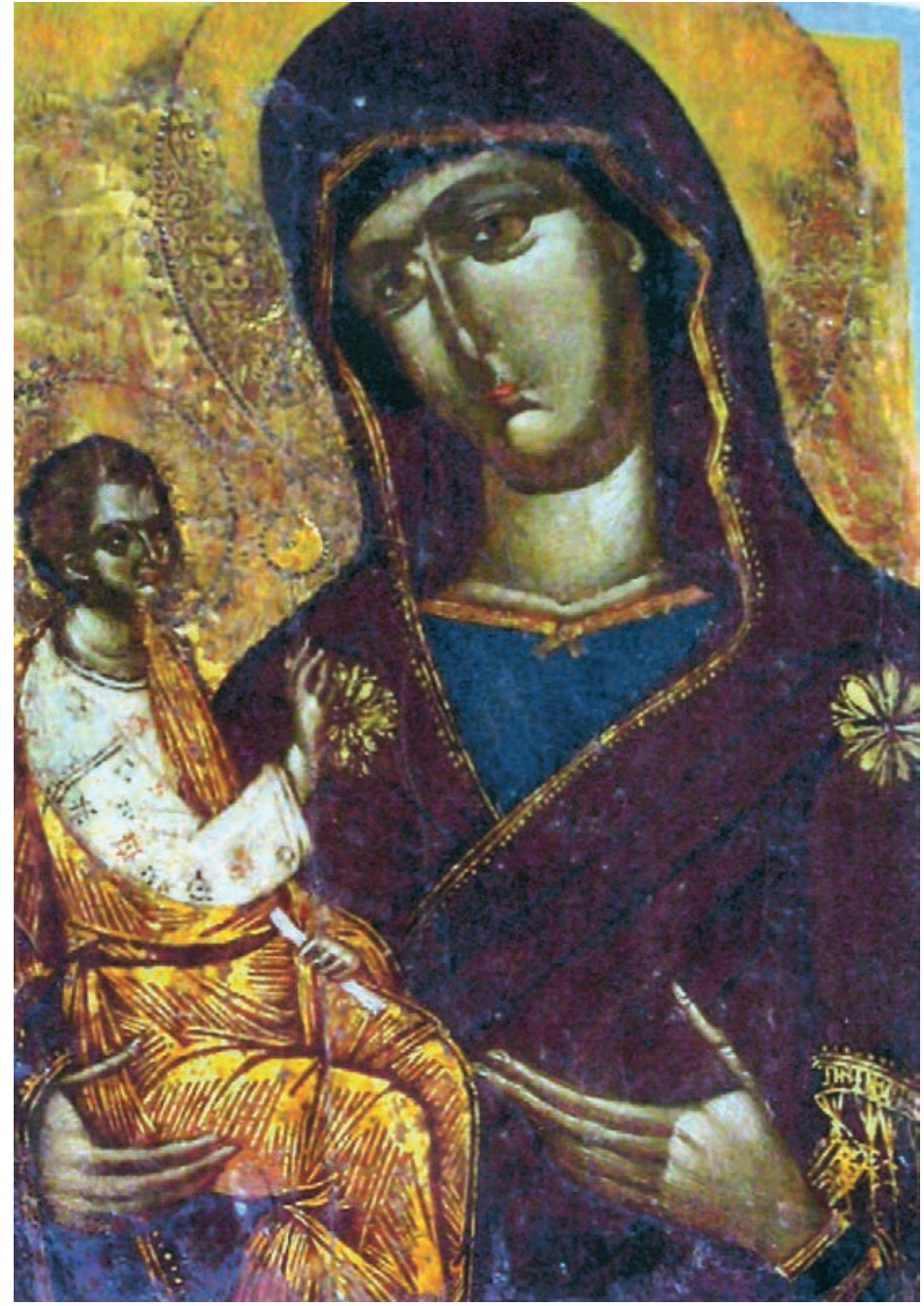

Sl. 5. Bogorodica s Djetetom, poč. 15. stoljeća, Šibenik, Dijecezanski muzej sv. Barbare (iz crkve sv. Duha u Šibeniku) Fig. 5. Virgin and Child, first half of $15^{\text {th }}$ century, Šibenik, Diocese Museum of Sacred Art (from St. Spirit church in Šibenik) rirane, s debelim obrvama koje su u kontrastu s bljedilom ozbiljnog Isusovog lica. Gospin maforion, vjerojatno potamnjene plave boje, u suprotnosti je s bijelim Isusovim hitonom tkanine posute sitnim ukrasima i s clavusom. Na ovoj je ikoni Bogorodice prepoznatljiv trokutni izrez maforiona i njegova zlatna obrubna traka. U oblikovanju inkarnata Gospina lica, za razliku od badijske Gospe

\footnotetext{
${ }^{29}$ T. ROSELLI DEL TURCO SASATELLI, „La chiesetta di San Martino dei Buonomini a Firenze“, Dedalo 1927-1928. Anno VIII, vol. III, 629.

${ }^{30}$ M. BACCI, „La „Madonna Costantinopolitana" nell abbazia di Sant Giustina di Padova“, Luca Evangelista Parola e immagine tra Oriente e Occidenta, catalogo de la mostra, Museo Diocesano Padova, 2000, G. MARIANI CANOVA (ed.), Padova 2000, 405-407; Idem, „Due tavolle della Vergine nella Toscana occidentale del primo duecento", Annali della Scuola Normale Superiore di Pisa, Serie IV, 2.1 1997., 36-53.

${ }^{31}$ Ibidem; V. PACE, „La chiesa abbaziale di Grottaferrata e la sua decorazione nel Medioevo", in Bollettino della Badia Greca di Grottaferrata, Nuova serie, Vol. XLI 1987, 64-66.

${ }^{32}$ C. ROSSI A. DE LUCA, The Treasures of the Monastery of Saint Catherine, The American University in Cairo Press, 2006, 70, 138.

${ }^{33}$ Byzantium Faith and Power (1261-1557), The Metropolitan Museum of Art, New York, 2004, H. EVANS (ed.), 348.
} 


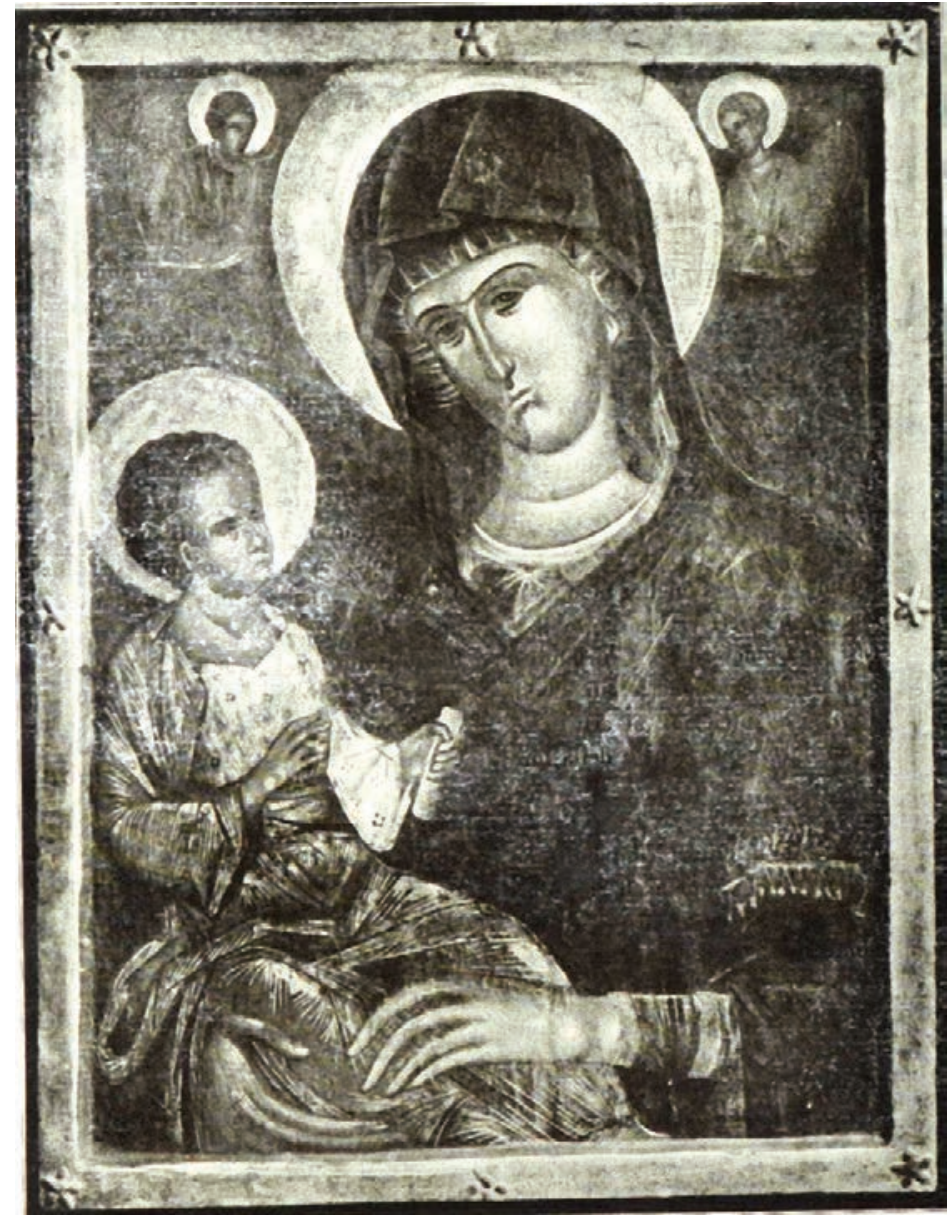

Sl. 6. Bogorodica s Dietetom, 13. st.(?), Firenze, San Martino dei Bonomini. Izvor: T. ROSELLI DEL TURCO SASATELLI, „La chiesetta di San Martino dei Buonomini a Firenze“, Dedalo 1927-1928. Anno VIII, vol. III, 629.

Fig. 6. Virgin with Child, $13^{\text {th }}$ century(?) Firenze, San Martino dei Bonomini. From: T. ROSELLI DEL TURCO SASATELLI,

"La chiesetta di San Martino dei Buonomini a Firenze", Dedalo 1927-1928. Anno VIII, vol. III, 629 gdje su vidljivi fini potezi kista, boja je nanošena u debelim slojevima, posebno oko prenaglašenog i zakrivljenog nosa koji se u korijenu spaja s isto tako istaknutim debelim crnim obrvama. Njihov je spoj naglašen sivim trokutom koji cijelom licu daje dramatičan i naglašeno arhaičan akcent. Zeleni podslik rasvijetljen je toplim okerom s primjesama ružičaste boje, a obrazi su naglašeni crvenim kružnicama koje su konturirane bijelim linijama. Vrat, koji nije toliko izdužen kao kod ikona iz Šibenika is Badije, rasvijetljen je bijelim zonama, a polukružnim su crtama naglašeni nabori kože. Ova se Bogorodičina ikona u smislu traženja prototipa povezuje s rimskom ikonom Sta Maria Nova/Santa Fransesca Romana iz 6. stoljeća, koja je „omekšavajući strogost Hodigitrije doprinijela širenju marijanskog kulta čudotvornošću i postala nositeljica pučkog štovanja, naročito od 12. stoljeća". ${ }^{34}$ Ikona iz Soluna zbog stila i ikonografije pripisuje se ciparskim radionicama. Detalj uspravljenog palca koji se odvaja od dlana i kojeg imaju i sve navedene dalmatinske ikone spomenute u ovom tekstu, karakterističan je za talijansko romaničko slikarstvo ${ }^{35}$ i nije poznat u Bizantu. Sjajna, gotovo individualizirana izražajnost ove Bogorodice s Djetetom, mnogi tehnički detalji među kojima su važne bijele konture, povezuju je sa slikarstvom Cipra gdje se u 12. i 13. stoljeću zbog političkih i kulturnih veza sa zapadom i križarima, razvio specifični mješoviti stil. ${ }^{36}$

Badijska Gospa od Otoka svojom je specifičnošću otvorila zanimljivo pitanje valorizacije ranih kretskih ikona u Dalmaciji. No valja analizirati i značenje ikone Bogorodice s Djetetom s druge strane Pelješkog kanala gdje Dubrovačka Republika u franjevačkoj crkvi nad Orebićima razvija štovanje Gospe od Anđela, vezujući je legendom za područje Žanjice u Boki Kotorskoj. ${ }^{37}$ Samostan je, ne slu-

\footnotetext{
${ }^{34}$ A. TOURTA, "The Virgin Dexiokraousa", Mother of God Represenation of the Virgin in Byzantine Art, Benaki Museum Athens, Skira Milano, 2000, 474-475.

${ }^{35}$ Ibidem.

${ }^{36}$ Ibidem; V. PACE, „Between East and West" Mother of God Represenation of the Virgin in Byzantine Art, Benaki Museum Athens, Skira Milano, 2000, 425-432. (sa starijom literaturom).

${ }^{37}$ A. CRNICA, Hrvati i Marija Nacrt djela Gospina Hrvatska, Zagreb, 1953, 147-148; J. VELNIĆ, „Samostan Gospe od Anđela nad Orebićima“, Spomenica Gospe Anđela u Orebićima, Omiš, 1970, 37-38; C. FISKOVIĆ, „Franjevačka crkva i samostan u Orebićima“, Spomenica Gospe Anđela u Orebićima, Omiš, 1970, 68-71; I. FISKOVIĆ, „Franjevački samostan i crkva Gospe Anđela nad Orebićima", Gospa od Anđela pratilac putnika i pomoraca 1470-1995, Orebić, 1995, 6-18; V. LUPIS, „Ikona Gospe od Anđela pratilac putnika i pomoraca“, Gospa od Andela pratilac putnika i pomoraca 1470-1995, Orebić, 1995, 19-32.
} 
čajno, postavljen na graničnoj i strateškoj točki Dubrovačke Republike, služeći i kao osmatračnica. Iskonski franjevački kult Gospe od Anđela ${ }^{38}$ vizualiziran je ovdje ikonom koja se štuje na bočnom polikromiranom i pozlaćenom drvenom oltaru. Unutar kompozitne cjeline s jasnim programom posttridentske reforme naglašavanja i vizualiziranja Gospina štovanja, ikona je označena natpisom koji je definira kao Regina coelorum i Domina angelorum. Kao i mnoge štovane starije slike umetnuta je u reljefnu palu portante s likovima anđela koji su veličinom i oblikom raspoređeni u četiri reda. Najveći su arhanđeli, svih sedam na broju, koji odjeveni u dugačke haljine adoriraju Gospu noseći svitke s marijanskim natpisima. ${ }^{39}$ Okružuje ih vijenac zakriljenih anđeoskih glavica, dok tri naga, znatno umanjena putta uznose Gospinu ikonu koju na samom vrhu kompozicije dva manja lebdeća anđela krune zlatnom krunom. Na vanjskom okviru retabla središnje mjesto zauzimaju kartuše s reljefnim likovima svetih prvomučenika Lovre i Stjepana koji su referenca na štovanje ovih svetaca u orebićkom kraju. ${ }^{40}$

Na blagdan Gospe od Anđela ikona se skidala iz oltara i umetala u svečani okvir-nosiljku koju pridržavaju dva lebdeća anđela stvarajući dojam uznošenja i lebdenja Gospina lika. I danas se nosi u procesiji. Po tradiciji koju su prenosili i širili franjevački kroničari i pisci, ikona je upravo ona čudotvorna slika za čije su štovanje 1479. godine u Podgorju nad Orebićem na zemljištu Dubrovačke Republike podignuti franjevačka crkva i samostan. ${ }^{41}$ Ona je na čudotvoran način doplovila s otočića Žanjice u Boki Kotorskoj spajajući tako i pomorsku i vjersku tradiciju oba kraja, pa su brodovi u prolazu, stoljećima, pa i danas, pozdravljali orebićku Gospu. Ikona je i na Pelješcu nastavila izvoditi razna ču-

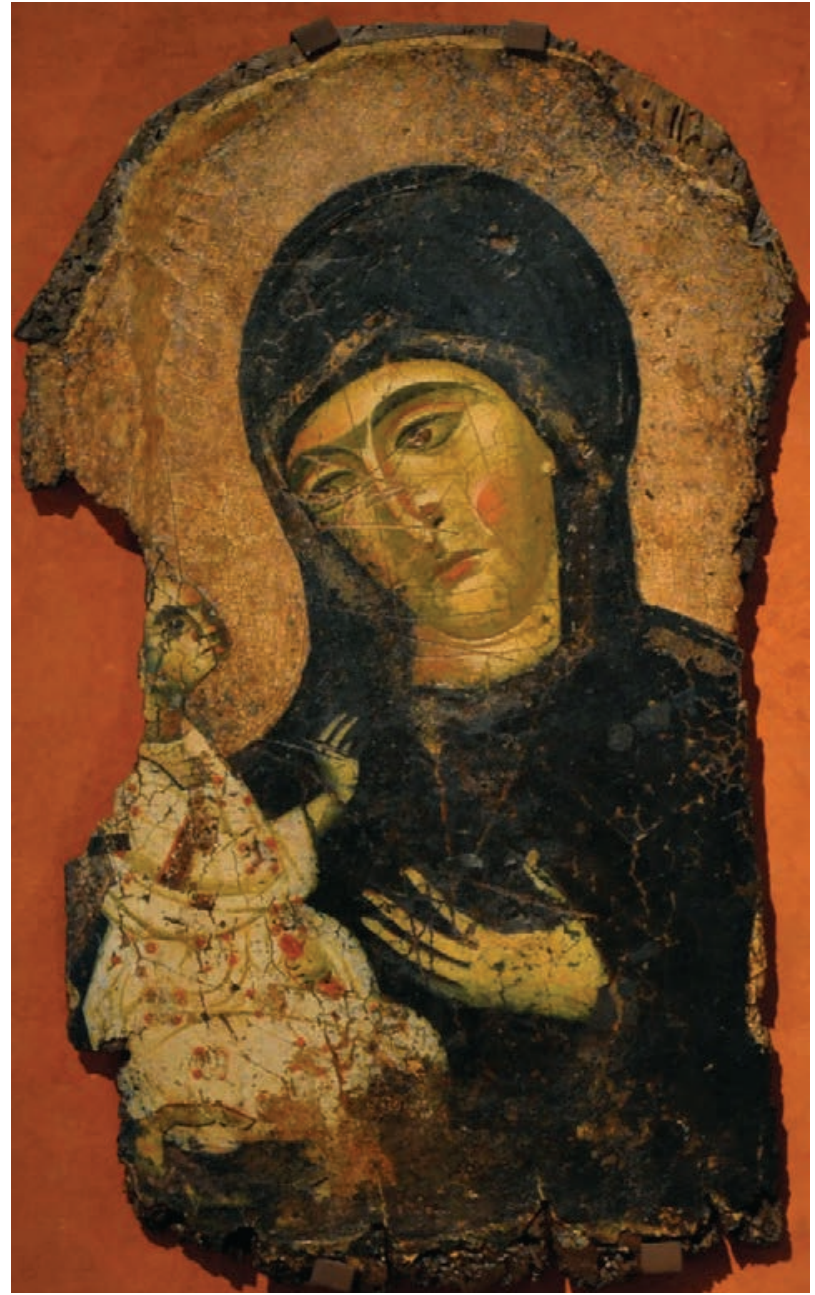

Sl. 7. Bogorodica Dexiokratousa, oko 1200., Thessaloniki, Museum of Byzantine Culture. Izvor:

Mother of God Represenation of the Virgin in Byzantine Art, ed, M. Vassilaki, Benaki Museum Athens Skira Milano 2000.

Fig. 7. Virgin Dexiokratousa, around 1200, Thessaloniki, Museum of Byzantine Culture. From: Mother of God Represenation of the Virgin in Byzantine Art, ed, M. Vassilaki, Benaki Museum Athens, Skira Milano 2000. desa, što je bila pretpostavka razvoja snažnog Gospina kulta kojeg su opsluživali franjevci. Stoljećima su joj vjernici prinosili zavjetne darove u različitim oblicima drvenih sličica, zavjetnih srebrnih pločica s likovima i(li) dijelovima tijela te nakitom. ${ }^{42}$

Ikona prikazuje Bogorodicu s Djetetom tipa Hodigitrije, ${ }^{43}$ ali Aristerokratouse. Dopojasni Gospin lik podigavši desnu ruku, pokazuje dijete Isusa. On, pak, okrenut majci, opruženih nogu sjedi na

\footnotetext{
${ }^{38}$ I. PRIJATELJ PAVIČIĆ, 176-177, 221-222, (n.11.).

${ }^{39}$ C. FISKOVIĆ, 68-69, (n.36.).

${ }^{40} \mathrm{Ibidem}$.

${ }^{41}$ Usp. (n. 36.)

${ }^{42}$ C. FISKOVIĆ, 116-117, (n.36.).

${ }^{43}$ V. LUPIS, 19-32, (n.36.); T. MIČEVIĆ ĐURIĆ Kretsko-venecijanske ikone Dubrovnika, magistarski rad obranjen u kolovozu 2008. god. na Filozofskom fakultetu Sveučilišta u Zagrebu, 127-129; Z. DEMORI STANIČIĆ, „Bogorodica s Djetetom "Gospa od Anđela", Milost susreta, Zagreb, 2010, S/18, 156-157.
} 


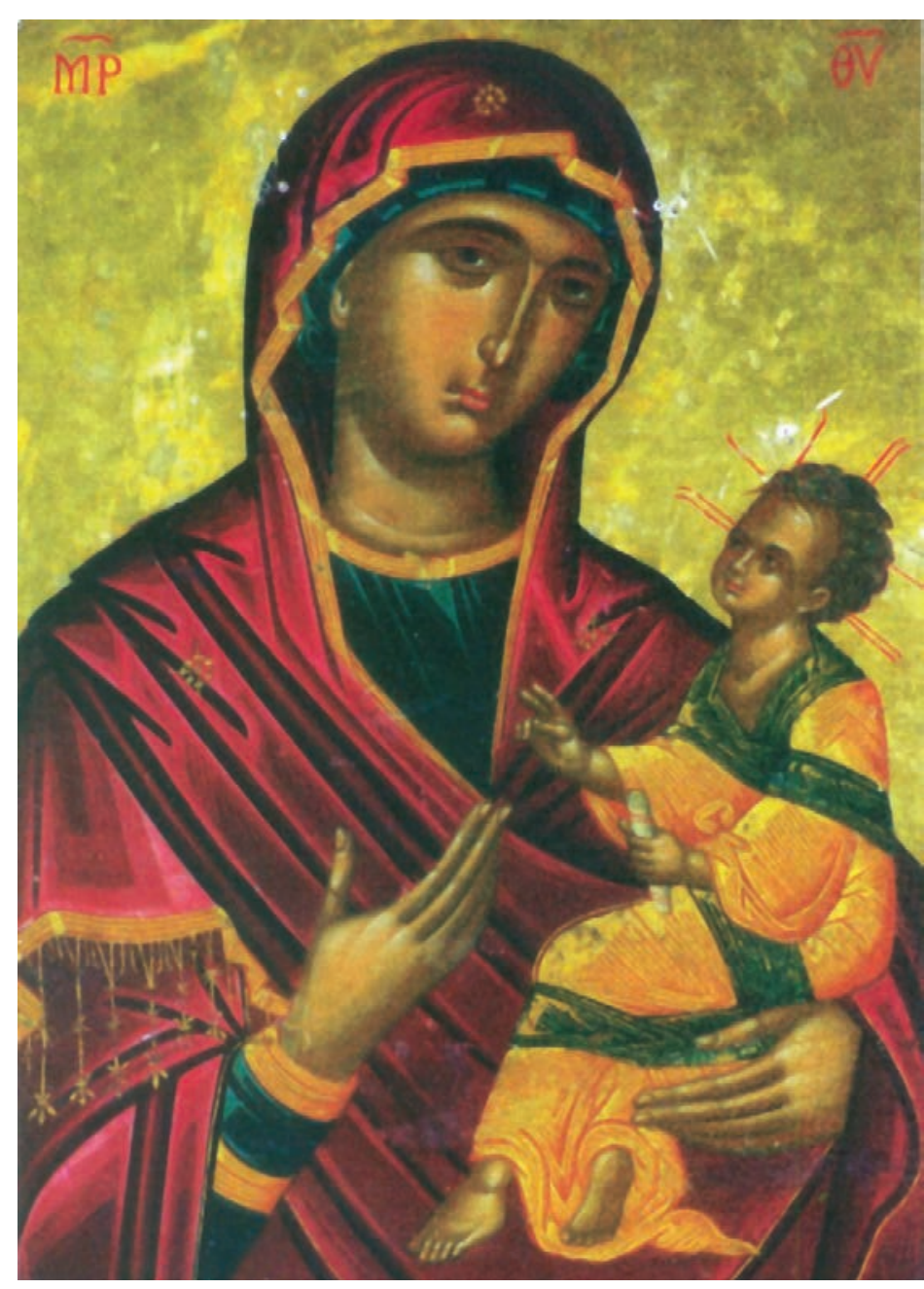

Sl. 8. Gospa od Anđela, druga pol. 16. st., Orebići crkva Gospe od Andela

Fig. 8. Virgin and Child "Our Lady of Angels", second half of $16^{\text {th }}$ century, Orebići, church of "Our Lady of Angels"

njezinoj lijevoj strani. Desnicom blagoslivlja, a u lijevoj ruci drži zatvoreni svitak, kojeg oslanja o koljeno. Bogorodica je lagano sagnula glavu, čime se, uz naznaku emocionalnog kontakta, omekšava strogost Hodigitrije. ${ }^{44}$ Zanimljivi detalj predstavlja Isusovo frontalno prikazano lijevo stopalo koje je boso, što u slikarstvu ikona simbolizira njegovu ljudsku ranjivost. Bogorodica je elegantno postavljena, izvijenog izduženog vrata i pravilnog lica. Oči su joj zasvedene lukom smeđih obrva, koje se spajaju u korijenu tankog dugačkog nosa. Izduženi narumenjeni obrazi zatvaraju njezino ovalno lice. Po tradiciji bizantskog slikarstva Isusovo je lice i ovdje prikazano kao u zrele osobe, izrazito visokog čela. Kosa mu je svjetlosmeđa, pravilno počešljana, s pramenovima koji padaju na čelo. I Bogorodica i Isus odjeveni su u svečanu carsku odjeću: ona ima tamnoplavi hiton zlatne bordure i purpurni maforion s resama i zlatnim zvijezdama nad čelom i na ramenima. $\mathrm{Na}$ glavi se pod maforionom nazire tamnoplava grčka kapa. Tkanine obrubljuje zlatna traka, a epimanikion-orukavlje sastavljeno je od vostruke vrpce. Krist je odjeven u žuto zlatni himation s umetcima od plavozelene trake, čiju je raskoš slikar naglasio zlatnim krisografijama. Bos je, bez sandala na nogama. Aureole nisu sačuvane: preostali su krakovi križa upisanog u Kristovu, uz uobičajene identifikacijske natpise s kraticama imena: MP $\Theta Y$, ICXC.

Slikarski tretman inkarnata i draperija otkriva kvalitetnog majstora: inkarnat je slikan glatkim pravilnim potezima kista. Podslik je sivo-maslinaste boje, dok je gornji sloj puti modeliran ružičastim tonovima. Konturiranje je ograničeno na oči i usne. Osvijetljena mjesta naglašena su kratkim bijelim šrafurama. Odjeća je naslikana na tipični bizantski način oblikovanjem kosih crvenih nabora unutar ploha konturiranih debelim tamnim linijama što naglašava linearnost i shematičnost. Isusova je odjeća ispunjena mrežom hrisografija.

Ikona Gospe od Anđela ima odlike kretskog slikarstva druge polovice 16. stoljeća kada su brojni slikari, od kojih tada već mnogi djeluju u Veneciji, standardizirali tehničku preciznost i tipologiju „klasicizirajućeg akademizama“. Prevladana je kreativnost iz 15. stoljeća koju su kretski slikari razvijali u kontaktu s venecijanskima koji dolaze na otok (koji je postao novi mletački posjed), i(li) tijekom vlastitih putovanja na istok i zapad gdje usvajaju izražajne elemente kojima modificiraju tradicionalno slikarstvo Bizanta. ${ }^{45}$ Upravo tom vremenu i stilu pripada ikona Gospe od Otoka, no proces

\footnotetext{
${ }^{44}$ M. BIANCO FIORIN, Pittura su tavolla di Trieste, Civici musei di storia ed arte, Trieste, 1975, kat. 10.

${ }^{45}$ Usp. (n. 5).

* Zahvaljujem kolegi Damiru Tuliću na ustupljenim fotografijama badijske Bogorodice te ikone iz Venecije.
} 
obnavljanja paleološkog bizantizma dovršen je u 16. stoljeću: usvojena je tehnika i postavljene su teme. Ikona Gospe od Anđela kvalitetan je standardizirani rad druge polovice 16. stoljeća, ali kao i na tisućama gotovo identičnih ikona koje se sreću od Grčke do različitih dijelova Europe, na njoj nema inovativnih ni kreativnih elemenata: svi dijelovi ove ikone dobro su „ugođeni“ i usklađeni, inkarnati su tonski modelirani i zaobljeni, a sjene puno mekše nego što su bile stoljeće prije.

Dvije ikone Bogorodice s Djetetom kretskih slikara različitog vremena nastanka i drugačijih stilskih odrednica razvile su jedna uz drugu snažne kultove koje vjernici časte do današnjih dana. Objema je povijesna faktografija pretvorena u legendu i obje su podjednako obilježile prostor pelješkog kanala. Gospa od Otoka neposredno je slijedila dolazak franjevaca na Badiju nakon utemeljenja njihovog samostana 1392. godine. Orebićka Gospa od Anđela mlađa je stotinjak godina, iako tradicija hoće da je to baš ona slika koja je 1479. doplovila do Trstenice i čije je štovanje i izlaganje dalo legitimitet izgradnji crkve i samostana. Iako slične, one su zrcalna slika jedna druge: Hodigitrija Dexiokratousa na Badiji i Hodigitrija Aristerokratousa u Orebićima unutar kultova koje su utemeljili i razvijali franjevci čašćene su od puka kao zaštitnice i zagovarateljice čovječanstva.

\section{TWO ICONS OF HODEGETRIA DEXIOKRATOUSA AND ARISTEROKRATOUSA FROM BADIJA AND OREBIĆI IN DALMATIA}

The oldest venerated icons in Dalmatia date form $13^{\text {th }}$ century. Although icons are mostly connected with the Orthodox Church they are much venerated in catholic west where they are elevated on altars but have prominent role within various forms of private devotion. After long centuries of historic and liturgical changes dozens of icons are still publicly venerated in Dalmatia and are exposed on altars, hanging on the church walls or confraternity halls. In time when Venetian Republic incorporated Dalmatian independent communes to its well organized state, icons of Virgin and Child became part of the elaborated concept of political propaganda on the vast area from Adriatic to Aegean Sea.

In widely dispersed veneration of Virgin which was successfully spread by icons, the role of mendicant orders is well known, as well as the commercial aspect of icon trade with a dominant role of Venetian merchants. Franciscans and Dominicans in Dalmatia had an important role in dissemination of veneration of icons inside their churches along the eastern shore of Adriatic from Rovinj to Dubrovnik, including competitiveness between confraternities they had founded. Franciscans were especially keen on promoting the veneration of icons establishing a strong cults of Virgin in Rab, Krapanj, Split, Hvar, Orebici, Badija, nourishing with the help of icons the preservation of old ways of public veneration within local traditions and customs.

In the Pelješac channel, between island and town of Korčula and peninsula Pelješac, two Franciscan monasteries are situated one opposite another. The first one is on the islet of Badija in front of the fortified town of Korčula. The other across the channel is on peninsula Pelješac just above the town of Orebići. Two Franciscan churches dedicated to Virgin Mary meet with their Marian icons within a small geographic area. In spite of Virgin as universal patroness, here within few miles two icons are placed and worshiped separately as result of political will. Even more, both churches belong to the Franciscan order but to different Franciscan provinces: Dalmatian on Badija and Franciscan province of the Republic of Dubrovnik in Orebici.

The first icon known as Our Lady of the Island, obviously due to its site, has been venerated for centuries, probably since 1392 when Franciscan friars came to the islet. Its cult was prominently spread after 1571 when Virgin liberated the town of Korčula from the siege of Muslim pirates who sacked the islands of Korčula and Hvar where had destroyed the cathedral and many other churches and villages. Only the town of Korčula resisted and its inhabitants gave thanks to Virgin's miraculous action and praised the icon which was previously evacuated from Badija. It all happened on the day of the Assumption. 
The icon of Our Lady of the Island, covered with richly ornate silver riza, obviously a votive gift as are silver crowns donated in 1597 by the city captain is a Hodegetria Dexiokratousa with particular stylistic features. Previously has been dated in $14^{\text {th }}$ and even $13^{\text {th }}$ century. But some details particularly Jesus' vivid child's face undoubtedly derive from Cretan icon painting, as well as the details of specific ornament of the gowns. In comparison to the published icon of the same type of Dexiokratousa from Venetian Scuola di San Rocco which has been dated towards the end of the $15^{\text {th }}$ century Badija icon was probably painted in the first half of that century. However, specific details on both icons open the discussion about the prototype of these Dexiokratousas. The very same type of Dexiokratousa is exhibited in the Ecclesial Museum in Šibenik and is even more expressive and archaic than the Badija icon so probably precedes it by one or two decades.

As has been pointed out in catalogue entries of few recent exhibitions the group of early Dexiokratousas has been connected to Cyprus painting, but the Badija icon is of Cretan origin, made in the period of artistic formation of that school and is the work of an innovative master.

The icon in constant contact, at least geographical, with Our Lady of the Island bears the name Our Lady of Angels and has a place on the other side of the Pelješac channel in Franciscan church which bears icon's appellative. It is a traditional Hodegetria Aristerokratousa placed within a wooden polychrome altar with posttridentine palla portante. This church and the monastery are situated, not by chance, on the very frontier between the Republic of Dubrovnik and Venetian Republic, and the position high on the slope of the mountain above the sea gives them strategic importance. Our Lady of Angels icon is a quality work by an obviously good Cretan painter from the second half of $16^{\text {th }}$ century, although Franciscan literal tradition always uses the legend about the icon's miraculous arrival from the region of Boka Kotorska when was found on the shores of Orebići.

Both these Cretan icons painted in different epochs and with different iconographic and stylistic features developed strong public veneration in which, continuing for centuries, people from both sides of the channel preserved devotion to them with festivities, pilgrimages and processions.

Key words: Cretan icons, Virgin and Child, Franciscan monasteries, Badija, Orebići

Ključne riječi: kretske ikone, Bogorodica s djetetom, franjevački samostani, Badija, Orebići 